\title{
INVESTORS' BEHAVIOR IN REGARD TO EARNINGS ANNOUNCEMENT DURING THE COVID-19 PANDEMIC: EVIDENCE FROM CAMBODIA
}

\author{
DOI: 10.17261/Pressacademia.2021.1446 \\ JBEF- V.10-ISS.3-2021(3)-p.127-137
}

Muhammad M. Ma'aji ${ }^{1}$, Lee Siang $\mathbf{H i}^{2}$

${ }^{1}$ CamEd Business School, Phnom Pehn, Cambodia. muhammad@cam-ed.com , ORCID: 0000-0003-0787-6411

${ }^{2}$ CamEd Business School, Phnom Pehn, Cambodia.

Isianghi@cam-ed.com , ORCID: 0000-0001-7732-4204

Date Received: July 22, 2021

Date Accepted: September 21, 2021

OPEN OACCESS (co)BY B

To cite this document

Ma'aji, M.M., Hi, L.S., (2021). Investors' behavior in regard to earnings announcement during the covid-19 pandemic: evidence from Cambodia. Journal of Business, Economics and Finance (JBEF), 10(3), 127-137.

Permemant link to this document: http://doi.org/10.17261/Pressacademia.2021.1446

Copyright: Published by PressAcademia and limited licenced re-use rights only.

\begin{abstract}
Purpose - The study investigates the reaction of investors to annual earnings releases as reflected in the share price movements of common stocks and volume of trade during the COVID-19 pandemic. The main gap this study aims to fill is whether earnings announcements possess informational value for investors during macroeconomic uncertainty in the wake of a pandemic.

Methodology - Event methodology is employed, and the returns in an event window, defined conventionally as the days before to days after a firm-specific public earnings announcement, are not abnormal.

Findings- We provide an apparent example where investors did not react to firm-specific positive and negative earnings announcements in the wake of the global pandemic. This could be influenced by the government response to COVID-19 as we have seen governments and central banks worldwide quickly enacted sweeping and sizable fiscal and monetary stimulus measures to limit the human and economic impact of the COVID19 pandemic. These types of government actions during economic downturns or crises have proved to helped stabilized the economy and increase confidence in the market in the short term and alleviate long-term consequences.

Conclusion- The study intended to contribute to the existing literature on earnings announcements by analyzing the information content of earnings announcements in a small Cambodian stock market during the COVID-19 pandemic period. Even though it was expected that positive or negative earnings announcements during a recession or economic downturn would result in significant price reactions from investors, the study has indicated that the information content of earnings announced by companies listed on CSX was beyond investors' interest. The puzzling price pattern following positive and negative earnings announcements on the Cambodian stock market could also be explained by behavioral principles, an issue to be addressed in further research. Cultural dimensions and their disparity between countries can also be reflected differently on pricing models.
\end{abstract}

Keywords: Event study, information and market efficiency, corporate earnings announcement, COVID-19, Cambodia market JEL Codes: G12, G14, C12

\section{INTRODUCTION}

Financial information about listed companies including takeover announcements, shareholder details, periodic earnings reports, asset acquisitions and disposals, dividend announcements, stock splits, company administrations, insider dealings to mention a few, are crucial while forecasting future performance and valuation of a company's equity. Investors consider this financial information when making investment decisions. Share prices of a company can rise and fall based on a company's financial information such as earnings performance. This is because earnings information reveals the financial health of a business. Earnings represent the measure of a firm's profits or loss from business activities and events during a stipulated period. Long-term investors may not be persuaded by one quarter of disappointing earnings, but some investors think more immediately and favor short-term 
profits. Earnings are not the only development investors focus on, but they are relevant during and before earnings season. Dividend and earnings announcements are commonly the two most important financial information used by the investors for deciding whether or not to buy or sell a particular company's share (Syed \& Bajwa, 2018; Ma'aji \& Abdullahi, 2014). Therefore, an announcement on a company's earnings is used in the stock market as a yardstick to assess the profitability and financial strength of any firm. Additionally, as the earnings news about a company is normally unpredictable, the stock market prior to the disclosure of the announcements, creates expectations and speculations about the announcements.

Investors in the market react differently to unexpected announcements of a firm's earnings if they differ from the market expectations. However, this reaction will entirely depend on whether the market is efficient or not. For the market to be considered efficient according to Fama (1991), financial markets are termed informationally efficient if security prices react to the announcement of new unanticipated information immediately, accurately, and in the right direction with no subsequent price trends. These timely and accurate adjustments to the share price indicate that the prices neither overreact nor underreact to any specific information announced. Therefore, investors cannot beat the market based on any set of new information, whether it is historical, publicly available information or private information (Fama, 1969). However, empirical studies have suggested that stock prices do not always accurately reflect available information. Stock markets under-react to information in some cases, while over-reacting in others (Barker \& Imam, 2008; Bloomfield, Libby, \& Nelson, 2002; Cready \& Gurun, 2010; Louhichi, 2008).

Furthermore, there is extensive literature that investigates the reflection of earnings announcements on the stock prices. During the last decades the information content of news and the capital market efficiency was tested by focusing on how the market reacts to earnings announcements. However, it must be noted that the main emphasis in respective researches is being put on the categories of earnings announcements (annual, semi-annual, quarterly, monthly, forecasts of earnings, analysts' ratings among others - as the most popular category), the types of earning announcement (commonly classify the announcements as "good" and "bad") as well as investor's overreaction for both good and bad earnings information (Piccoli et al., 2017; Spyrou et al., 2007; Piccoli \& Chaudhury, 2018). However, the reaction to investors earnings announcements on share prices during macroeconomic-uncertainty in the wake of a financial difficulties or a pandemic is being analyzed only by a few authors (Angelovska, 2017a; Johnson \& Zhao, 2012; Salminen, 2008). Angelovska, (2017b) found that investors in Macedonia did not react to companies' positive earnings news during economic uncertainty. The findings do not coincide with Salminen (2008), who found that the abnormal returns during the recession were positively slightly higher than during the boom, and Johnson (1999), who found that investors during a recessionary period of the business cycle will be more interested in assessing the information nature of earnings announcements by observing the share price movement around the public announcement of earnings.

This study aims to investigate investor's reaction to earnings announcements on share prices during macroeconomic-uncertainty in the wake of COVID-19 pandemic by employing an event study methodology to observe the share price movement across listed companies on Cambodia Securities Exchange (CSX). The main gap this study aims to fill is whether earnings announcements possess informational value for investors during macroeconomic-uncertainty in the wake of a pandemic. Therefore, the specific objectives are to investigate the behavior of the share prices after the event day and if the volume is usual within the event window.

\section{LITERATURE REVIEW}

\subsection{COVID-19 and Government Stimulus}

The novel coronavirus (COVID-19) pandemic has caused a crisis for the global economy and markets. As a consequence of the COVID-19 no business, industry, or economy has been spared from the devastating effects of the pandemic as it shut down many countries' economies for a number of months in order to control the spread of the infectious disease. This has disrupted different macroeconomic or industry factors in the economy such as supply chains across international boundaries, demand for goods and services domestically and overseas, and in the labor force supply. However, despite these challenges, some industries have naturally taken the impact much harder than others, such as airlines, financial institutions, oil and gas, restaurants, live event companies, tourist companies, movie theaters, and many more. But these are hardly not the only one's suffering. Each industry is experiencing its own unique set of challenges that are threatening to undermine a thriving and booming business environment. This can largely be attributed to decreased consumer confidence as consumers globally continue to experience a decrease in income and expect a longer-lasting impact on their routines and finances as a result of the COVID-19 (Mckinsey, 2020). Therefore, these changed business conditions in light of the COVID-19 pandemic will affect corporate earnings and consequently will cause companies to review their dividend policies. Chief financial officers (CFOs) of many organizations are becoming increasingly pessimistic about the impact COVID-19 will have on their top and bottom lines, according to a new survey from 
PricewaterhouseCoopers (PwC). The result of the survey indicates that about 80 percent of the CFOs and other finance leaders expect COVID-19 to decrease revenue and/or profits in 2020 (PwC, 2020).

Furthermore, in response to this crisis, governments and central banks worldwide quickly enacted sweeping and sizable fiscal and monetary stimulus measures to limit the human and economic impact of the COVID-19 pandemic. The hope is to avoid a longterm economic recession due to coronavirus lockdowns. Previous studies have shown that government actions during economic downturn or crisis have helped to stabilized the economy and increase confidence in the market (Agnello, \& Sousa, 2011; Al-Eyd \& Barrell, 2005; Checherita, Nickel \& Rother, 2009; Hemming, Kell \& Mahfouz, 2002; Ma'aji, Rahima \& Hadi, 2014; Somani, 2015). Decreasing the federal funds rate appears to be the most practical way for the government to change expectations, increase confidence in the market and thereby increase stock prices (Somani, 2015). Fiscal policy actions can have significant multiplier effects when undertaken in the outcome of severe housing busts, therefore, suggesting the importance of the implementation of fiscal stimulus packages (Agnello \& Sousa, 2011). Moreover, increases in government spending during financial crisis is likely to be more effective in supporting the economy than tax reductions, while tax cuts seem to work better in the longer run but their effectiveness fades away in the medium to long run (Al-Eyd \& Barrell, 2005; Hemming, Kell \& Mahfouz, 2002). Higher social transfers usually have a quick positive impact if well targeted to credit-constrained households, but if persistent, they tend to be detrimental to long-term growth by creating distortions in the allocation of resources and impending labour mobility (Checherita, Nickel \& Rother, 2009).

\subsection{Earnings Announcements}

The section reviewed the empirical studies around earnings announcements. Investors' reaction to earnings announcements has gained a lot of attention in modem finance literature. This is because share prices of a company can rise and fall based on a company's earnings performance. Earnings information reveals the financial health of a business and its future prospects. However, the findings on investors' reaction to earnings announcements are contradictory. Additionally, Brown (1979) examined the adjustment of stock prices to earning per share (EPS) information and results suggested that statistically significant cumulative abnormal returns appeared from day 15 to day 45 . This indicated that the market failed to adjust instantaneously to the new EPS information and provided an opportunity to earn excess returns on the EPS information after 45 days of announcement. Bernard and Thomas (1990) found statistically significant abnormal returns after quarterly earnings announcements. A higher-thanexpected earnings announcement is found to have a positive cumulative average abnormal return (CAAR) and tend to move the share price higher (Cready \& Gurun, 2010). Similarly, Barker and Imam (2008) found that investors viewed companies with higher earnings more favorably than a company with low earnings. Hussin et al. (2010) found that lower earnings lead to negative market reaction. Earnings announcements usually contain information which is not publicly available to investors, thus the reaction (Ball \& Kothari, 1991; Jegadeesh \& Livnat, 2006). Accordingly, managers take actions to avoid announcing lower than expected earnings or earnings surprises, as managers believe that such announcements would lead to large negative price reactions and negative publicity (Burgstahler \& Eames, 2006). CEOs are even willing to forgo positive net-present-value projects just to add to the earnings per share (EPS) to meet market expectations (Graham et al., 2005).

Furthermore, studies have recently examined how investors react to earnings announcements during macro-economic uncertainty. During economic uncertainty, investors tend to lose confidence in the market and become more concerned about corporate earnings due to increased future uncertainty (Todorov, 2010). Investors react little less to earnings announcements during economic uncertainty where they attribute bad (good) performance to bad (good) luck rather than to less (more) managerial effort and/or ability during uncertain periods (Stein \& Wang, 2016). Furthermore, based on investors' aversion to uncertainty, studies found that there is a larger investors reaction to bad news compared to good news following increased macrouncertainty (Williams, 2015; Bird \& Yeung, 2012). Investors react more to negative earnings announcements (bad news) than a positive earnings announcement (good news) with increased economic uncertainty. Uncertainty-averse investors take a conservative approach and place more weight on negative news than on positive news following an increase in uncertainty. However, Angelovska (2017) finds that investors in Macedonia did not react to companies' positive earnings news during economic uncertainty. Additionally, Ball and Shivakumar (2008) report that earnings announcements provide a modest but not overwhelming amount of information in relation to the market. During the financial crisis, investors were exposed to an unusually high volume of dramatic and unexpected news (Dzielinski 2011). Receiving (too) much information can result in information overload which stimulates status-quo bias, thus potentially reducing individual investors' trading activity during the crisis (Agnew \& Szykman 2005). Glaser and Weber (2005), for example, find an increase in the standard deviation of individual investors' return and volatility forecasts directly after September 11 and the subsequent stock-market turmoil. 
On the other hand, individual investors earn a significantly weak positive excess return after the day of the earnings announcement while institutional investors do not earn excess return before or after the announcement (Dey \& Radhakrishna, 2008). New earnings information exerts its full influence on the stock price within an hour of announcement (Bernard \& Thomas, 1990). The abnormal market performance occurred prior to the release of the earnings report. This suggests that although earnings are meaningful measures of a firm's financial performance, by the time they are published they are no longer news and have little or no impact on the market (Davis, Piger, \& Sedor, 2012). Das, Pattanayak, and Pathak (2008) found no evidence of significant abnormal returns around quarterly earnings announcements and it could not be established whether the share price drifts are positive in the case of good announcements or negative in the case of bad announcements. Similarly, Hawaldar (2018) conclude that there is no significant difference between the number of positive and negative average abnormal returns (AARs) and based on the CAAR, investors who bought shares either before or after the announcement of quarterly financial results and held them would have earned abnormal returns that are not attributable to market factors. Therefore, the study concludes that the reaction of Indian stock market to the announcement of quarterly financial results is very slow. The finding is consistent with the study by Iqbal and Mallikarjunappa (2011), Iqbal (2014) and Hawaldar (2016). An event study methodology is employed to test the following hypotheses:

Ho: Expected abnormal return is zero for each stock for each day t in the event window.

H1: Expected abnormal return is different from zero for each stock for each day $t$ in the event window.

\section{DATA AND METHODOLOGY}

The study adopts an event study methodology to analyze investors reactions to earnings announcements and the impact of the announcement share price around the event period. Event study methodology has been used extensively in finance, economics and political economy literature to empirically estimate market reactions to specific events by studying the reactions of relevant variables around the event window. The methodology is based on the assumption that capital markets are efficient and the effects of an event will be reflected immediately in the stock price. Normal rate of return means the expected rate of return of the testing period if the event did not occur. An event study analysis could determine whether there is an 'abnormal' return associated with an unanticipated event. The event of interest is the public announcement of earnings, and the event date is the first day on which such an announcement is made.

The market model which provides a linear specification of the return of the given stock to the return of the market portfolio is applied to help gauge the expected returns and to illustrate abnormal returns around the event date. The abnormal return is the difference between the realized return observed from the market and the benchmark return. The benchmark return is supposed to be the return of the stock if there is no event. This model is adopted because it reduces the variance of abnormal returns by removing the portion of the stock return that is related to variation in the market return. The abnormal return is determined as the residual of the market model expressed in (1).

$R_{i t}=\alpha_{i}+\beta_{i} R_{m t}+\varepsilon_{i}$

Where $R_{i t}$ is the return of stock $i$,

$R_{m t}$ is the return of market index,

$\beta_{i}$ is systematic risk of stock $i$,

$\varepsilon_{i}$ is the error term.

The empirical model can be stated as follows: when an event occurs, market participants revise their beliefs causing a shift in the firm's return-generating process. Ordinary least squares (OLS) regression is performed to estimate the coefficients of the market model separately for each event using the non-event return data. The estimated coefficients, $\alpha_{i}$ and $\beta_{i}$ are used to form predictions of $R_{i t}$ during the event period. Thus, the abnormal return for security $i$ on event day t A $R_{i t}$, is calculated as:

$\varepsilon_{i t}=A R_{i t}=R_{i t}-\alpha_{i}-\beta_{i} R_{m t}$

We test each firm in our sample for abnormal returns for every day in the event window, using the methodology proposed by Brown and Warner (1985). Abnormal returns or excess returns were computed by subtracting the normal return of the security from actual return of any security over the event window. In this paper, the estimation period is defined as 70 days before the event window and a 21-day event window (observation period) is used to calculate the abnormal returns of the security and 21 days' event window consists of 10 trading days before (anticipation days) and 10 trading days after the event (adjustment days) (Ball and Kothari, 1991; Capstaff et al., 2004; Hussin et al., 2010). A t-statistic for each firm for each day in the event window 
(defined as 10 days, i.e., -10 to -1 , before the announcement day to 10 days after the announcement day, i.e., +1 to +10 ) is calculated. Our null hypothesis is that excess returns for each day are equal to zero.

The mean abnormal return across event observations on day $\mathrm{t}$ denoted as $\overline{A R} \mathrm{t}$, is the sum of individual abnormal returns on day t divided by the number of events $(\mathrm{N})$,

$\overline{A R} \mathrm{t}=\frac{1}{N} \sum_{i=1}^{n} A R_{i, t}$

These $\overline{A R}$ t were average for all the five stocks in the analysis summed over the event window to calculate the cumulative average abnormal return (CAAR) as follows:

$C A A R_{k}=\sum_{k} \overline{A R}_{i, t}$

where: $k=-10, \ldots, 0.0, \ldots,+10$. The CAAR is a useful statistical analysis in addition to the AR because it helps us get a sense of the aggregate effect of the abnormal returns. Particularly if the influence of the event during the event window is not exclusively on the event date itself, the CAAR can prove very useful.

To find out if the volume is unusual during corporate earnings announcements, the average standardized volume was calculated. First, an individual share's daily volume ( $\mathrm{Vi}$ ) in a particular day $\mathrm{t}$ is divided by the average daily volume (Vie) for that share in the event period $(e=-80$ to +10$)$.

$\bar{V}_{i t}=\frac{V_{i}}{\bar{V}_{i e}}$

This gives us a normalized measure that is independent of firm size. Second, the normalized volume for each share is averaged across all shares for each day.

$\bar{V}_{i t}=\frac{1}{N} \sum_{i=1}^{n} \bar{V}_{i t}$

Table 1: Company Earnings Announcement in Cambodia (2020-2021)

\begin{tabular}{ccccc}
\hline Company Ticker & Event window & Event date & Earning (million KHR) & Year-on-year change \\
\hline GTI & $17 / 12 / 2019-28 / 04 / 2020$ & $09 / 04 / 2020$ & 5,545 & $-4.22 \%$ \\
PAS & $09 / 12 / 2019-22 / 04 / 2020$ & $01 / 04 / 2020$ & 43,463 & $-3.77 \%$ \\
PPAP & $09 / 12 / 2019-22 / 04 / 2020$ & $01 / 04 / 2020$ & 46,806 & $42.84 \%$ \\
PPSP & $23 / 01 / 2020-09 / 06 / 2020$ & $26 / 05 / 2020$ & 61,636 & $699.24 \%$ \\
PWSA & $21 / 02 / 2020-10 / 07 / 2020$ & $26 / 06 / 2020$ & 33,292 & $-54.77 \%$ \\
\hline
\end{tabular}

Note: Grand Twins International (Cambodia) Plc (GTI), Sihanoukville Autonomous Port (PAS), Phnom Penh Autonomous Port (PPAP), Phnom Penh SEZ PIc (PPSP), Phnom Penh Water Supply Authority (PWSA). Date format (dd/mm/yy)

Furthermore, the study is based upon listed companies on Cambodia Securities Exchange (CSX) that released their annual financial reports released, during 2019-2021. The daily returns of all the seven stocks listed on the CSX Index, published by CSX, are used for analyses. The daily closing prices and the daily volumes of trade are extracted from the official website of the CSX. The daily returns are computed based on the closing price of each trading day. Event day is defined as a day when any company made the annual financial report announcement and the company's share was traded on that day $(t=0)$. For each event in the sample, a maximum of 91 daily returns are hand-collected. Given the limitations of the data-collecting process, we chose to limit the period under study within the period when COVID-19 was first announced as a global pandemic 2019-2020. The dates and times of the company news announcements have been listed in Table 1 ; it is taken to be the day on which the news was first reported on CSX. Despite COVID-19, some Cambodian companies reported good earnings that should be rejoice by the investors as shown in Table 1.

\section{FINDINGS AND DISCUSSIONS}

The market model using equation (1) is calculated by each year, and estimated coefficients are shown in Table 2 . These are coefficients that explicate the relationship between the stock and the market. Beta is the stock's sensitivity to market return (the slope coefficient) and measures the sensitivity of a particular stock to general market movements or returns. It measures the 
systematic risk based on how returns co-move with the overall market. The level of sensitivity is between $0.12 \%$ and $1.61 \%$. The coefficients are significant at 10\% (GTI, PPSP and PWSA), 5\% (PPAP) and 1\% level (PAS).

Table 2: OLS Coefficients Estimate Using Equation (1)

\begin{tabular}{|c|c|c|c|}
\hline Company Ticker & intercept $\left(\alpha_{i}\right)$ & $\operatorname{Beta}\left(\beta_{i}\right)$ & $R^{2}$ \\
\hline GTI & -0.00166 & $0.35327^{*}$ & 0.04357 \\
\hline PAS & 0.00064 & $1.61157^{* * *}$ & 0.96337 \\
\hline PPAP & -0.00181 & $0.24702 * *$ & 0.08508 \\
\hline PPSP & -0.00058 & $0.19698 *$ & 0.02458 \\
\hline PWSA & -0.00104 & $0.11718^{*}$ & 0.04230 \\
\hline
\end{tabular}

Figure 1: AAR and CAAR Across All 5 Stocks over the Estimation Window

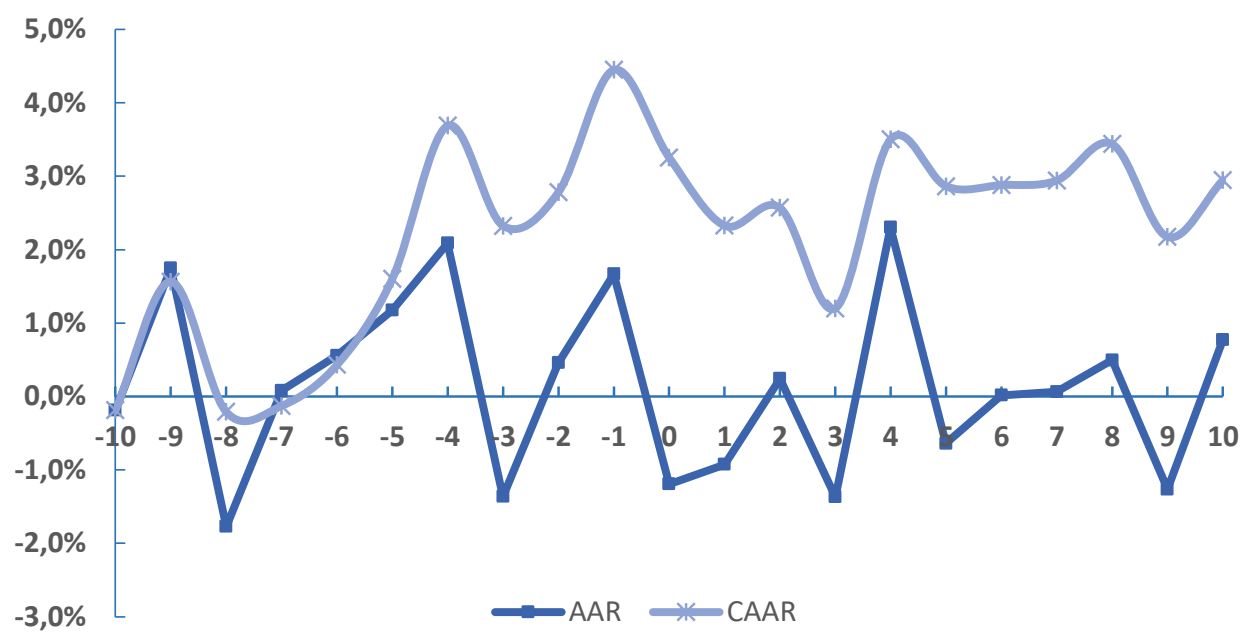

As indicated in Figure 1, the CAAR plot show that to some extent the market gradually learns about the forthcoming announcement. The average CAAR gradually drifts up in Day 3 before the announcements most probably due to anticipation of the announcements. In the days after the announcement, the CAAR is relatively volatile, as would be expected. Furthermore, the CAAR start moving upward 7 days before the event, and it reaches a peak 4 days before the earnings announcements are made. Additionally, the CAAR start moving upward again 2 days before the earnings announcements and surprisingly, it becomes negative a day prior to announcements, and it stays negative until the third day after the announcement is made. It comes to positive range from Day 5 onward after the event. The AR also behaves in the same manner, except it again touches back the positive value at the fourth day after the announcement.

As discussed in methodology, we apply t-statistics to test the statistical significance of aforementioned AR and CAR for each stock. Appendix 1 present the results of the $t$-statistics within the event window ( -10 to +10 days) for AR of each stock. It is evident from the results that the absolute value of AR is greater in the case of the GTI and PPSP compared to PAS, PPAP and PWSA. This observation is true for the anticipation window, adjustment window and day of the event. This specifies that compared to PAS, PPAP and PWSA, market reacts more strongly in GTI and PPSP sample.

The results of the t-statistics within the event window ( -10 to +10 days) for AR shows few significant abnormal returns before and after the earnings announcement for each stock. The AR for GTI where only found to be significant for Day 1, 4, 8 and 9 before the announcement while the rest of the days in the event window especially after the announcement were found not to be significant. Additionally, the AR for PAS where only significant for Day 4 and 5 before the announcement and Day 2, 5 and 8 after the announcement while the rest of the days are insignificant. For PWSA, the significant days appeared to be immediately after 
the announcement (Day 1, 2 and 3) while for PPAP and PPSP only one day appeared to be significant throughout the event window. Moreover, in all the five stocks analyze, the event has not created significant impact on the share price on the announcement day. The movement of share prices is not influenced by the announcement. Sharma (2020) shows that COVID-19 has a statistically significant effect on stock volatility, but the impact actually varies with countries involved, with the markets in higher-income countries overreacting in the beginning and bouncing back more rapidly than lower-income countries.

Furthermore, the none responses and reaction by Cambodian investors to the companies' earnings announcement as empirically evidence could be influence by the government in response to COVID-19. We have seen governments and central banks worldwide quickly enacted sweeping and sizable fiscal and monetary stimulus measures to limit the human and economic impact of the COVID-19 pandemic. The hope is to instill confidence in the short- term and avoid a long-term economic recession due to coronavirus lockdowns. Previous studies have shown that government actions during economic downturn or crisis have helped to stabilized the economy and increase confidence in the market (Agnello, \& Sousa, 2011; Al-Eyd \& Barrell, 2005; Checherita, Nickel \& Rother, 2009; Hemming, Kell \& Mahfouz, 2002; Somani, 2015).

Table 4: CAAR T-Statistics for Combined Days in Window

\begin{tabular}{ccccc}
\hline Windows & Number days & CAAR & t-stat & p-value \\
\hline$(-1,+1)$ & 3 & $-0.455 \%$ & -0.12029 & 0.905 \\
$(-2,+2)$ & 5 & $0.245 \%$ & 0.05023 & 0.960 \\
$(-3,+3)$ & 7 & $-2.488 \%$ & -0.43086 & 0.668 \\
$(-4,+4)$ & 9 & $-3.138 \%$ & -0.47927 & 0.633 \\
$(-5,+5)$ & 11 & $2.434 \%$ & 0.33626 & 0.738 \\
$(-6,+6)$ & 13 & $3.009 \%$ & 0.38229 & 0.703 \\
$(-7,+7)$ & 15 & $3.151 \%$ & 0.37274 & 0.710 \\
$(-8,+8)$ & 17 & $1.876 \%$ & 0.20839 & 0.836 \\
$(-9,+9)$ & 19 & $2.362 \%$ & 0.24824 & 0.805 \\
$(-10,+10)$ & 21 & $2.945 \%$ & 0.29442 & 0.769 \\
\hline
\end{tabular}

Note: $*, * *, * * *$ indicates significance at $10 \%, 5 \%$ and $1 \%$ level respectively. CAAR is the cumulative average deviation of actual returns of a security from expected returns of all the five stocks in the analysis.

Therefore, to obtain robust results, we developed the CAR by aggregating AR to test the significance of return in combined days in the event window (such as $-1,+1 ;-2,+2 ;-4,+4$; etc.). These results as shown in table 4 for CAR t-statistics indicate that the reaction of the stock returns in the selected windows do not appears to be statistically significant. Therefore, if the corporate announcement has an effect on stock prices, we would expect to see rejections of the null hypothesis on each day in the event window. Rejections in the event window are not found. This suggests that corporate announcements in our sample have no impact on returns. If the corporate announcement has an effect on stock prices, we would expect to see rejections. The findings are not consistent with Salminen (2008), who found that the abnormal returns during the recession were positively slightly higher than during the boom, and Johnson (1999), who found that investors during a recessionary period of the business cycle will be more interested in assessing the information nature of earnings announcements by observing the share price movement around the public announcement of earnings. 
Figure 2: Average Standardized Volumes over the Estimation Window

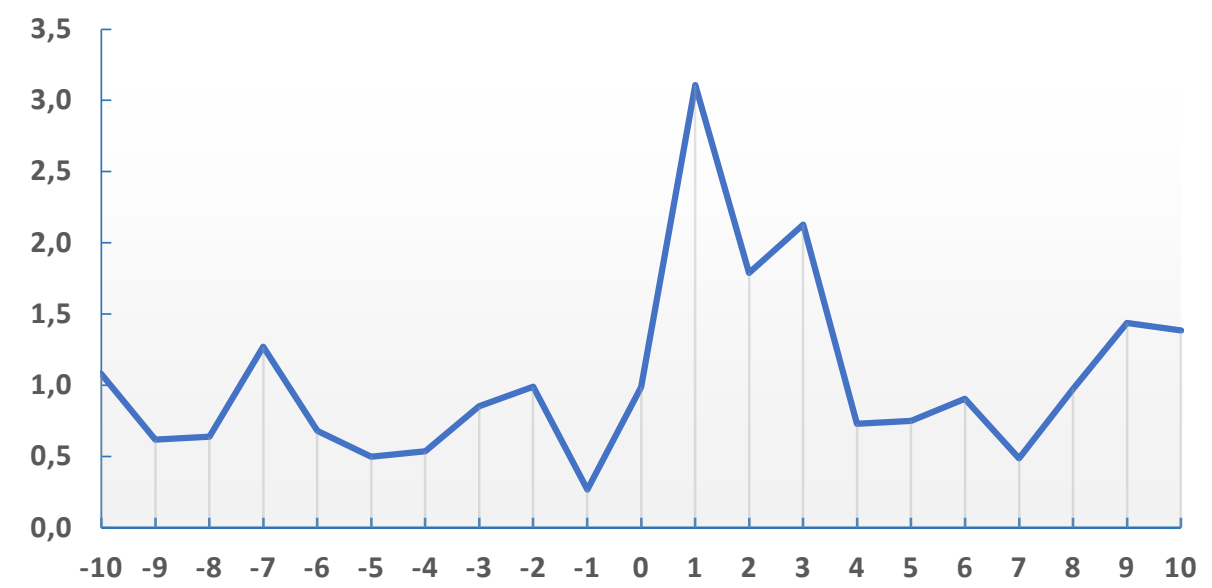

To find out if the volume is unusual during the event window period, the standardized average across the stocks volume is calculated. Figures 2 plot this daily volume figure in the event period $(-10$ to +10$)$. As can be seen, there is sharp increase on Day 1 before the announcement, on the announcement day and then a sharp decrease in the standardized average volume back to the usual volume observed in the event window. In the market microstructure literature, high volumes are associated with information arrivals (Kyle, 1985). In general, we could observe that there is no unusual volume in the event window.

\section{CONCLUSION}

In this study, we compute abnormal return for individual stocks and the cumulative average abnormal return around earnings announcements to measure the information efficiency of earnings announcements on the Cambodian Securities Exchange (CSX). To investigate the announcements' effects, we used event study approach to probe investor's reaction to corporate earnings announcements made by the listed companies on CSX. First, we estimated normal returns, using market model; subsequently, these returns were used to calculate abnormal returns for the share price. This study aimed at investigates investor's reaction to the announcement in the wake of COVID-19 pandemic on CSX, scrutinizing the impact of information efficacy in earnings announcement and existence of abnormal returns. Empirical evidence demonstrates that the Cambodian investors did not react to the companies' earnings announcement. The null hypothesis could not be rejected in favor of the alternate hypothesis. The none responses and reaction by Cambodian investors to the companies' earnings announcement as empirically evidence could be influence by the government in response to COVID-19. We have seen governments and central banks worldwide quickly enacted sweeping and sizable fiscal and monetary stimulus measures to limit the human and economic impact of the COVID-19 pandemic. The hope is to instill confidence in the short- term and avoid a long-term economic recession due to coronavirus lockdowns.

The study intended to contribute to the existing literature on earnings announcements by analyzing the information content of earnings announcements in a small Cambodian stock market during the COVID-19 pandemic period. Even though it was expected that positive or negative earnings announcements during recession or economic downturn would result in significant price reaction from investors, the study has indicated that the information content of earnings announced by companies listed on CSX was beyond investors' interest. The puzzling price pattern following positive and negative earnings announcement on the Cambodian stock market could also be explained by behavioral principles, an issue to be addressed in further research. Cultural dimensions and their disparity between countries can also be reflected differently on pricing models. Further research on corporate stock prices' reactions requires the direction of corporate events and investors' behavior towards these events and the information they get indicators that enable them to evaluate their performance and determine their value in the financial market.

\section{Acknowledgement}

This research is fully supported by CamEd Business School, Phnom Pehn, Cambodia, therefore the authors wish to express their gratitude to CamEd Business School for the financial support. 


\section{REFERENCES}

Agnello, L., \& Sousa, M. (2011). Can fiscal policy stimulus boost economic recovery? Dans Revue Economique, $62(6), 1045$ - 1066.

Agnew, J. R., \& Szykman, L. R. (2005). Asset allocation and information overload: The influence of information display, asset choice, and investor experience. The Journal of Behavioral Finance, 6(2), 57-70.

Al-Eyd, A., \& Barrell, R. (2005). Estimating tax and benefit multipliers in Europe. Economic Modelling, 22, 759-776.

Angelovska, J. (2017a). Investors' behaviour in regard to company earnings announcements during the recession period: evidence from the Macedonian stock exchange. Economic Research-Ekonomska Istraživanja, 30(1), 647-660.

Angelovska, J. (2017b). The impact of financial crisis on the short-term interaction between Balkan stock markets. UTMS Journal of Economics, $8(2), 53-66$.

Ball, R., \& Kothari, S. P. (1991). Security returns around earnings announcements. Accounting Review, 718-738.

Ball, R., \& Shivakumar, L. (2008). How much new information is there in earnings? Journal of Accounting Research, 46(5), 975-1016.

Barker, R., \& Imam, S. (2008). Analysts' perceptions of earnings quality. Accounting and Business Research, 38(4), 313-329.

Bernard, V. L., \& Thomas, J. K. (1990). Evidence that stock prices do not fully reflect the implications of current earnings for future earnings. Journal of Accounting and Economics, 13(4), 305-340.

Bird, R., \& Yeung, D. (2012). How do investors react under uncertainty? Pacific-Basin Finance Journal, $20(2), 310-327$.

Burgstahler, D., \& Eames, M. (2006). Management of earnings and analysts' forecasts to achieve zero and small positive earnings surprises. Journal of Business Finance \& Accounting, 33(5-6), 633-652.

Checherita, C., Nickel, C., \& Rother, P. (2009). The role of fiscal transfers for regional economic convergence in Europe. ECB Working Paper, 1029.

Cready, W. M., \& Gurun, U. G. (2010). Aggregate market reaction to earnings announcements. Journal of Accounting Research, 48(2), $289-334$.

Das, S., Pattanayak, J. K., \& Pathak, P. (2008). The effect of quarterly earnings announcements on Sensex: A case with clustering of events. The IUP Journal of Accounting Research and Audit Practices, 7(4), 64-78.

Davis, A. K., Piger, J. M., \& Sedor, L. M. (2012). Beyond the numbers: Measuring the information content of earnings press release language. Contemporary Accounting Research, 29(3), 845-868.

Dey, M. K., \& Radhakrishna, B. (2008). Who profits from trading around earnings announcements? Evidence from TORQ data. Journal of Asset Management, 9(4), 300-308.

Dzielinski, M. (2011). News sensitivity and the cross-section of stock returns. NCCR FINRISK, 719.

Fama, E. (1991). Efficient capital markets: II. Journal of Finance, 46(5), 1575-1617.

Fama, E., Fisher, L., Jensen, M., \& Roll, R. (1969). The adjustment of stock prices to new information. International Economic Review, $10(1), 1-15$.

Graham, J. R., Harvey, C. R., \& Rajgopal, S. (2005). The economic implications of corporate financial reporting. Journal of Accounting and Economics, 40(1-3), 3-73.

Hemming, R., Kell, M., Mahfouz, S. (2002). The effectiveness of fiscal policy in stimulating economic activity - a review of the literature. IMF Working Paper, WP/02/2008.

Hawaldar, I. T. (2016). The reaction of Bahrain bourse to announcement of annual financial results. International Review of Business Research Papers, 12(1), $64-75$.

Hawaldar, I. (2018). Reaction of stock prices to earnings announcements. Asian Journal of Multidimensional Research (AJMR), 7(9), $282-293$.

International Monetary Fund (2020). Policy Tracker. International Monetary. Available at, https://www.imf.org/en/Topics/imf-andCOVID19/Policy-Responses-to-COVID-19\#U

Iqbal, T., Mallikarjunappa, T. (2011). Efficiency of stock market: A study of stock price responses to earnings announcements. Published by LAP Lambert Academic Publishing Company, Germany.

Iqbal, T. (2014). Seasonal analysis of abnormal returns after quarterly earnings announcements. International Journal of Accounting and Financial Reporting, 4(2), 501-519.

Jegadeesh, N., \& Livnat, J. (2006). Post-earnings-announcement drift: The role of revenue surprises. Financial Analysts Journal, 62(2), 22-34. 
Johnson, M. (1999). Business cycles and the relation between security returns and earnings. Review of Accounting Studies, $4(2), 93-117$.

Johnson, W. B., \& Zhao, R. (2012). Contrarian share price reactions to earnings surprises. Journal of Accounting, Auditing \& Finance, 27(2), 236266.

Kyle, A. (1985). Continuous Auctions and Insider Trading. Econometrica, 53, 1315-1335.

Libby, R., Bloomfield, R., \& Nelson, M. W. (2002). Experimental research in financial accounting. Accounting, Organizations and Society, 27(8), 775810.

Louhichi, W. (2008). Adjustment of stock prices to earnings announcements: evidence from Euronext Paris. Review of Accounting and Finance, $7(1), 102-115$.

Ma'aji, M., Abdullahi, S. (2014). Market reaction to international cross-listing: evidence from Nigeria. International Journal of Information Technology and Business Management, 27(1), 13-25.

Ma'aji, M., Rahima A., Hadi, A. (2014). Performance of asset and commodity-based securities in Malaysia's Islamic inter-bank money market. Journal of Islamic Banking and Finance, 2(2), 1-13.

Mckinsey, (2020). Consumer sentiment evolves as the next "normal" approaches. Available at, https://www.mckinsey.com/businessfunctions/marketing-and-sales/our-insights/a-global-view-of-how-consumer-behavior-is-changing-amid-COVID-19

Piccoli, P., \& Chaudhury, M. (2018). Overreaction to extreme market events and investor sentiment. Applied Economics Letters, 25(2), $115-118$.

Piccoli, P., Chaudhury, M., Souza, A., da Silva, W. V. (2017). Stock overreaction to extreme market events. The North American Journal of Economics and Finance, 41, 97-111.

PwC, (2020). PwC's COVID-19 CFO Pulse: Insights from global finance leaders on the crisis and response. Available at https://www.pwc.com/gx/en/issues/crisis-solutions/COVID-19/global-cfo-pulse.html

Salminen, J. (2008). Abnormal returns of dividend announcements during a boom and a recession. Empirical evidence from US from the years of 2000-2002 and 2005-2007 including Finnish Extra Dividends. Master's Thesis, Lappeenranta University of Technology, Finland.

Sharma, S. (2020). A note on the Asian market volatility during the COVID-19 pandemic. Asian Econ Letters, https://doi.org/10.46557/001c.17661

Somani S. (2015). The Effects of government policies on the stock market. Caravel Undergraduate Research Journal, available at https://sc.edu/about/ offices_and_divisions/research/news_and_pubs/caravel/archive/2015/2015-caravel-stock-market.php

Spyrou, S., Kassimatis, K., Galariotis, E. (2007). Short-term overreaction, underreaction and efficient reaction: Evidence from the London Stock Exchange. Applied Financial Economics, 17(3), 221-235.

Stein, L., Wang, C. (2016). Economic uncertainty and earnings management. Harvard Business School Accounting \& Management Unit Working Paper, 16-103. Available at https://ssrn.com/abstract=2746091

Syed, A. M., \& Bajwa, I. A. (2018). Earnings announcements, stock price reaction and market efficiency-the case of Saudi Arabia. International Journal of Islamic and Middle Eastern Finance and Management, 11(3), 416-431.

Todorov, V., (2010). Variance risk-premium dynamics: The role of jumps. Review of Financial Studies, 23(1), 345-383.

Williams, C. D. (2015). Asymmetric responses to earnings news: A case for ambiguity. The Accounting Review, 90(2), 785-817. 
Appendix 1: Results of the test statistics for ARs and corresponding p-values in 21 days' event window for each company

\begin{tabular}{|c|c|c|c|c|c|c|c|c|c|c|}
\hline \multirow[b]{2}{*}{ Day } & \multicolumn{2}{|c|}{ GTI } & \multicolumn{2}{|c|}{ PAS } & \multicolumn{2}{|c|}{ PPAP } & \multicolumn{2}{|c|}{ PPSP } & \multicolumn{2}{|c|}{ PWSA } \\
\hline & AR & p-value & AR & $p$-value & AR & $p$-value & AR & $\mathrm{p}$-value & AR & p-value \\
\hline-10 & $-0.14 \%$ & 0.97 & $-0.85 \%$ & 0.17 & $1.76 \%$ & 0.28 & $-1.05 \%$ & 0.72 & $-0.65 \%$ & 0.66 \\
\hline-9 & $7.92 \%$ & $0.02^{* *}$ & $-0.11 \%$ & 0.86 & $-0.68 \%$ & 0.67 & $1.46 \%$ & 0.61 & $0.16 \%$ & 0.92 \\
\hline-8 & $-9.66 \%$ & $0.00^{* * *}$ & $-0.14 \%$ & 0.83 & $2.20 \%$ & 0.17 & $-0.13 \%$ & 0.96 & $-1.13 \%$ & 0.44 \\
\hline-7 & $0.22 \%$ & 0.95 & $-0.33 \%$ & 0.60 & $0.20 \%$ & 0.90 & $0.10 \%$ & 0.97 & $0.21 \%$ & 0.89 \\
\hline-6 & $2.46 \%$ & 0.46 & $0.31 \%$ & 0.62 & $0.45 \%$ & 0.78 & $-0.71 \%$ & 0.81 & $0.28 \%$ & 0.85 \\
\hline-5 & $0.20 \%$ & 0.95 & $-1.32 \%$ & $0.04^{* *}$ & $5.28 \%$ & $0.00^{* * *}$ & $0.06 \%$ & 0.98 & $1.64 \%$ & 0.27 \\
\hline-4 & $9.71 \%$ & $0.00^{* * *}$ & $1.15 \%$ & $0.07^{*}$ & $-0.95 \%$ & 0.56 & $0.57 \%$ & 0.84 & $-0.05 \%$ & 0.97 \\
\hline-3 & $-4.35 \%$ & 0.19 & $-0.32 \%$ & 0.61 & $-2.08 \%$ & 0.20 & $0.09 \%$ & 0.97 & $-0.17 \%$ & 0.91 \\
\hline-2 & $0.15 \%$ & 0.96 & $0.98 \%$ & 0.12 & $0.92 \%$ & 0.57 & $0.18 \%$ & 0.95 & $0.06 \%$ & 0.97 \\
\hline-1 & $9.42 \%$ & $0.01^{* * *}$ & $-0.09 \%$ & 0.89 & $-0.72 \%$ & 0.65 & $0.08 \%$ & 0.98 & $-0.36 \%$ & 0.81 \\
\hline 0 & $-1.62 \%$ & 0.63 & $-0.12 \%$ & 0.84 & $-2.61 \%$ & 0.11 & $-1.70 \%$ & 0.56 & $0.08 \%$ & 0.95 \\
\hline 1 & $-2.11 \%$ & 0.52 & $-0.05 \%$ & 0.94 & $-0.78 \%$ & 0.63 & $-4.78 \%$ & $0.10^{*}$ & $3.09 \%$ & $0.04 * *$ \\
\hline 2 & $0.07 \%$ & 0.98 & $-1.30 \%$ & $0.04^{* *}$ & $0.32 \%$ & 0.84 & $-0.88 \%$ & 0.76 & $3.00 \%$ & $0.04^{* *}$ \\
\hline 3 & $-0.32 \%$ & 0.92 & $0.92 \%$ & 0.14 & $0.14 \%$ & 0.93 & $-4.32 \%$ & 0.14 & $-3.27 \%$ & $0.03^{* *}$ \\
\hline 4 & $1.19 \%$ & 0.72 & $0.36 \%$ & 0.57 & $2.29 \%$ & 0.16 & $7.62 \%$ & $0.01 * *$ & $0.07 \%$ & 0.96 \\
\hline 5 & $-1.77 \%$ & 0.59 & $-3.12 \%$ & $0.00^{* * *}$ & $0.40 \%$ & 0.80 & $0.77 \%$ & 0.79 & $0.51 \%$ & 0.73 \\
\hline 6 & $-0.19 \%$ & 0.95 & $0.98 \%$ & 0.12 & $-0.51 \%$ & 0.75 & $0.05 \%$ & 0.99 & $-0.25 \%$ & 0.87 \\
\hline 7 & $0.04 \%$ & 0.99 & $0.36 \%$ & 0.57 & $0.08 \%$ & 0.96 & $0.76 \%$ & 0.79 & $-0.93 \%$ & 0.53 \\
\hline 8 & $-1.06 \%$ & 0.75 & $1.06 \%$ & $0.09 *$ & $0.09 \%$ & 0.95 & $2.21 \%$ & 0.44 & $0.17 \%$ & 0.91 \\
\hline 9 & $-4.14 \%$ & 0.21 & $-0.57 \%$ & 0.36 & $0.02 \%$ & 0.99 & $-1.74 \%$ & 0.55 & $0.11 \%$ & 0.94 \\
\hline 10 & $1.86 \%$ & 0.57 & $-0.15 \%$ & 0.81 & $1.54 \%$ & 0.34 & $0.14 \%$ & 0.96 & $0.46 \%$ & 0.76 \\
\hline
\end{tabular}

Note: ${ }^{*}, * *, * *$ indicates significance at $10 \%, 5 \%$ and $1 \%$ level respectively. Grand Twins International (Cambodia) PIc (GTI), Sihanoukville Autonomous Port (PAS), Phnom Penh Autonomous Port (PPAP), Phnom Penh SEZ PIC (PPSP), Phnom Penh Water Supply Authority (PWSA). First column (Days) shows 21 days' event window. 10 to -1 are 10 days before event, 0 is the event day and 1 to 10 days are 10 days after event day. AR is the deviation of actual returns of a security from expected returns. 